\title{
Zkušenosti s užitím online dotazníku na www.csfd.cz jako součásti smíšeného výzkumu
}

\author{
Experiences with the online questionnaire on www.csfd.cz as a part of mixed research
}

\author{
Jana Krátká
}

\begin{abstract}
Abstrakt: Audiovizuální fikční příběhy sledujeme obvykle za účelem relaxace nebo zábavy, za účelem sdílení zkušeností s postavami a učení se ze sociálních situací. Naše výzkumné cíle vycházejí z potřeby vědět, co již lidé znají a jak probíhá jejich interakce s audiovizuálními fikčními př́běhy. Podle výzkumných zkušeností nejrůznějších autorů se jako nejvhodnější jeví interpretativní metody, založené na dialogu a interakci s ostatními, nicméně z důvodu zaměření tohoto výzkumu do doposud nereflektované oblasti identifikace s fikční postavou filmů a seriálů a zkušenostního učení jsme využili jak kvantitativních, tak kvalitativních metod. Tento příspěvek se zaměřuje především na zkušenosti se sběrem dat prostřednictvím nejnavštěvovanějších domácích internetových stránek o filmu www.csfd.cz.
\end{abstract}

Klíčová slova: online dotazník, výzkum, audiovizuální fikční příběhy

\begin{abstract}
Audiovisual fictional stories are usually watched for the purpose of relaxation, fun or sharing experiences with characters and learning from the social situations. Our research aims results from need to know, what people know and how their interaction with audiovisual fictional stories proceeds. According to the research experiences of several authors the interpretative methods, based on dialogue and interaction, seem to be optimal. Nevertheless from the reason of orientation of this research into not-reflected area of identification with fictional character of films and TV series and experiential learning, we used qualitative, as well as quantitative methods. This article focuses on experiences with data collection through Czech most visited website about film www.csfd.cz.
\end{abstract}

Keywords: online questionnaire, research, audiovisual fictional stories

\section{1 Úvod}

Filmové a seriálové příběhy ovlivňují náš život obvykle výrazněji, než si uvědomujeme. Stejně neuvědomované bývá naše učení $\mathrm{v}$ tomto prostředí. Výhody takového informálního učení přitom spočívají právě ve skutečnosti, že jsme neformálně vedeni k přemýšlení o sobě a okolním světě. Toto přemýšlení, realizované formou sebereflexe nebo diskusí s lidmi se společnými zájmy, může vést k hlubší životní orientaci, upřesňování nebo dokonce změně postojů a hodnot. Cílem prezentovaného výzkumného projektu bylo přinést zkušenosti $\mathrm{s}$ výzkumem $\mathrm{v}$ oblasti informálního zkušenostního učení prostřednictvím fikčních postav a jejich př́iběhů. 


\section{Výzkum}

\subsection{Výzkumné cíle}

Výzkumné cíle celého projektu byly formulovány poměrně široce:

1) Nabídnout možné vysvětlení vztahu mezi audiovizuální fikcí, fikčními postavami a identifikací na straně diváka. Mezi dílčí cíle patří: Rozpoznat vztah mezi vlastnostmi postav a vlastnostmi diváka; Uspořádat typologii identifikovaných postav; Popsat oblasti tzv. „následkư“ identifikačního procesu; Ověřit, že divák je ve volbě postavy aktivní; Ověřit, že se divák identifikuje s převážně kladnými postavami.

2) Popsat a dále analyzovat průběh identifikačního procesu jako jádra zkušenostního učení prostřednictvím fikčních postav a jejich příběhů (zejména emocionální a sociální učení, vliv na rozvoj osobnosti). Předpokládáme, že identifikační proces probíhá na základě sebereflexe.

3) Ověřit vztah mezi fanouškovstvím a identifikací s fikční postavou.

4) Nalézt vztah mezi identifikací s fikční postavou a mediálně kritickým přístupem. Předpokládáme, že se tyto prvky vzájemně nevylučují.

5) Výzkumné výsledky, které nejsou primárním předmětem tohoto př́ispěvku, čtenár̆ nalezne v monografii „Zkušenostní učení prostřednictvím identifikace s fikčními postavami filmů a seriálư““ (Krátká, 2010).

\subsection{Volba výzkumných nástrojů}

Při volbě metody jsem vyšla ze zkušeností autorů srovnatelných studií a metodologického trendu v oblasti fan studies (srov. Alasuutari, 1999 in Harrington \& Bielby, 2007; Hills, 2002 in Harrington \& Bielby, 2007), kteří se přiklánějí k etnografickým studiím, které jsou považovány za víceméně ideální způsob studování současného přijetí médií. Jako nejvhodnější se jeví interpretativní metody, založené na dialogu a interakci s ostatními (srov. Fisherkeller, 2000). Z důvodu zaměření tématu do výzkumem doposud nereflektované oblasti identifikace s fikční postavou filmů a seriálů a zkušenostního učení bylo využito jak kvantitativních, tak kvalitativních metod. Kvalitativně zjištěné údaje zásadně rozšiřují a potvrzují data získaná kvantitativním šetřením.

Na základě dosavadních poznatků, včetně zkušeností autorů relevantních studií (Buckingham, 1987; Jones, 2003) byl vytvořen dotazník, který sloužil současně také jako kontaktní formuláŕ pro získání a výběr některých respondentů kvalitativně zaměřené části výzkumu.

Pro kvalitativní ověření výsledků získaných dotazníkovým šetřením byly využity případové studie především proto, že jsem usilovala o porozumění podobným př́padům na základě důkladného prozkoumání jednoho př́ípadu (srov. Hendl, 2005). Právě rozhovory s fanoušky a oddanými diváky (srov. Reeves et al., 1996) mohou nejlépe napomoci porozumění naším vztahům $\mathrm{k}$ fikčním postavám. Př́padové studie mohou ideálním způsobem ilustrovat teoretické poznatky a empirická data, $v$ některých př́ípadech je dále rozvést, případně vyvrátit.

\section{Zkušenosti s užitím webového dotazníku na www.csfd.cz}

\subsection{Volba Česko-Slovenské filmové databáze jako mista výzkumu}

Aby bylo možné definované výzkumné oblasti a obecná tvrzení alespoň pro účel tohoto výzkumu empiricky prokázat, zajímal mě velmi specifický typ respondentů - mladí lidé, kteří 
jsou s fikcí pravidelně konfrontováni a považují ji za nedílnou součást svého každodenního života.

Distribuce dotazníku byla zajištěna prostřednictvím nejnavštěvovanějších domácích internetových stránek o filmu www.csfd.cz (v době sběru dat bylo registrováno více než 120 000 uživatelů), což zajistilo výběr respondentů různého pohlaví, vzdělání, atd. (mezi uživateli webu jsme však předpokládali především mládež) z celé České i Slovenské republiky. Jako fanoušky je bylo možné definovat mimo jiné proto, že jsou tito uživatelé aktivními hodnotiteli filmů a seriálů prostřednictvím tzv. hvězdičkování, a také prostřednictvím psaní vlastních komentár̆ù.

Česko-Slovenská filmová databáze představuje v souladu s termínem „open education“ místo, v němž jsou znalosti a myšlenky odborníků i fanoušků volně sdíleny prostřednictvím internetu a vzájemně předávány. Jedná se o internetovou databázi filmů a seriálů, která od roku 2001 současně sdružuje jejich fanoušky. U skupiny respondentů spojených registrací a aktivní účastí na rozsáhlé internetové databázi lze oprávněně předpokládat, že jsou $\mathrm{s}$ audiovizuální fikcí v pravidelném kontaktu.

Př́ijemnou zkušeností z výzkumu byl poměrně seriózní př́stup většiny respondentů, ironické situace nastávaly, když se mezi respondenty objevovali naši studenti, což jen svědčí o přirozeně a ideálně získaném souboru respondentů. Viz např.

Isherwood: Źe by nám právě kvůli tomuhle začinal seminár̆ Teorie a metodiky o týden později? Nuž co, vyplnit to vyplním. :)

Moogwi: ted'ka jsem ten dotazník vyplnil, doufal sem že mi to vyplivne nějaký výsledky a ono nic...:( nevadí

H34D: Moogwi: Napadlo mě to :) Ale radši jsem to pojal "seriózně"...

Jako motivační prvek byla použita soutěž o originální DVD a úvodní slovo vysvětlujícího smysl projektu. Samotný výzkumník byl odkázán jednak svojí příslušností k Masarykově univerzitě, jednak je sám jedním z dlouholetých uživatelů csfd.cz, což také přispělo $\mathrm{k}$ vstřícnému postoji uživatelů. Dotazník mohl být odeslán zcela anonymně, respondent uvedl své jméno a adresu pouze v př́ípadě, že se chtěl zúčastnit soutěže. Pokud měl respondent zájem o další spolupráci (např. rozhovory o oblíbených postavách), mohl uvést svoji csfd.cz přezdívku, což později usnadnilo jeho dohledání a individuální oslovení. Tento způsob byl např. využit pro př́padovou studii o recepci a divácích TV seriálu „How I Met Your Mother“, kdy více než 50 respondentů v dotazníku uvedlo, že se ztotožňují s některou z postav seriálu a současně měli zájem o další spolupráci na výzkumu. Z oslovených uživatelů se kvalitativního šetření později zúčastnilo 13 osob.

\subsection{Průběh dotaznikového sběru dat}

Od spuštění dotazníku, 17. 9. 2008 ve 20 hodin do jeho zastavení 25. 9.2008 v 11 hodin bylo získáno 2169 použitelných dotazníků. Nejvíce jich přicházelo v průběhu prvních dnů ve večerních hodinách přibližně do 1 hodiny ráno, potom přírůstek mírně klesal, ale nikdy nenastala hodina, v jejímž průběhu by nikdo nevyplnil a neodeslal alespoň jeden dotazník. Ještě v poslední den přicházelo 5-10 vyplněných dotazníků za hodinu, nicméně jsme již došli k závěru, že množství získaných respondentů bude dostačující. Náš předpoklad nebyl př́liš konkrétní, protože csfd.cz byla $\mathrm{k}$ výzkumným účelům využita úplně poprvé. $\mathrm{V}$ anketách csfd.cz je vždy běžná účast minimálně 10000 respondentů, ale u rozsáhlejšího dotazníku jsme 
zájem uživatelů nedokázali přesně odhadnout. Byli jsme však připraveni získat minimálně 1000 respondentů. Zájem se ukázal jako nečekaný a současně uživatelé vyjadřovali hlubší zájem o jeho provedení a výsledky.

Odkaz na dotazník byl pro uživatele webu snadno viditelný a př́istupný z horního banneru hlavní stránky, který se načítá spolu s každou další stránkou. Od spuštění dotazníku bylo možné sledovat reakce uživatelů jednak na obecném diskusním fóru csfd.cz, jednak v rámci připomínek zaslaných do soukromé pošty nebo na e-mail.

Respondenti také byli pozorní vůči označení celého výzkumného projektu „Vzory pohyblivého obrazu: recepce filmu a audiovizuální kultury u současné české mládeže“, jehož meze $\mathrm{v}$ ryze českém kontextu se od počátku realizace projektu ukazovaly jako umělé a neudržitelné. Nejen v kvantitativní části výzkumu, ale také u všech sledovaných prrípadových studií se přirozeně prolínali čeští a slovenští diváci/fanoušci, které by nebylo přirozené oddělovat, protože v oblasti recepce audiovizuální kultury představují stejnou jazykovou skupinu (sledující obvykle s titulky v češtině, slovenštině nebo často také v angličtině). Vlastní diskuse mezi fanoušky pak probíhají simultánně v češtině a slovenštině.

Někteří uživatelé, kteří se výzkumného šetření zúčastnili, od počátku vyjadřovali zájem o výsledná zjištění. Tento zájem byl později typický pro naprostou většinu respondentů, kteří byli objektem př́padových studií v kvalitativně orientovaných částech výzkumu. Na konci sběru dat bylo taktéž na hlavní stránce Česko-Slovenské filmové databáze zveřejněno závěrečné slovo s poděkováním za účast a vyhodnocena soutěž a 5 náhodně vybraných respondentů dostalo speciální 2DVD Tenkrát na Západě.

Také s průběhem kvalitativních šetření tyto zkušenosti byly pozitivní, jejich respondenti se především zajímali o zjištěné výsledky, viz napřr.

Markéta: Byla jsem mozna vice uprimna i sama $k$ sobe, nez jsem cekala. SATC me rozhodne ovlivnil a teprve pri premysleni nad tvymy otazkami mi doslo jak moc... (...) Take bych docela rada znala nakonec vysledky tve prace - je nejak mozne se $k$ nim potom dostat? rada bych si to precetla, ceho jsem vlastne soucasti. Dej vedet.

\section{Závěr}

Realizace dotazníku na stránkách Česko-Slovenské filmové databáze dobře zajistila získání dat poměrně velkého vzorku filmových a seriálových fanoušků, který jsem chtěla získat. Množství dat můžeme prezentovat na př́kladu získaných typů fikčních postav, s nimiž se respondenti ztotožňují: Někteří respondenti neuvedli postavu žádnou, jiní uvedli jednu až tři postavy. Celkem jsem tak získala přibližně 2300 ztotožňovaných postav nejrůznějších vlastností, které mohly být následně okódovány v rozsahu 60 otevřených typů a nakonec se sjednotit do 7 typů postav podle respondenty ztotožňovaných vlastností. Následující grafy charakterizují výzkumný vzorek. 


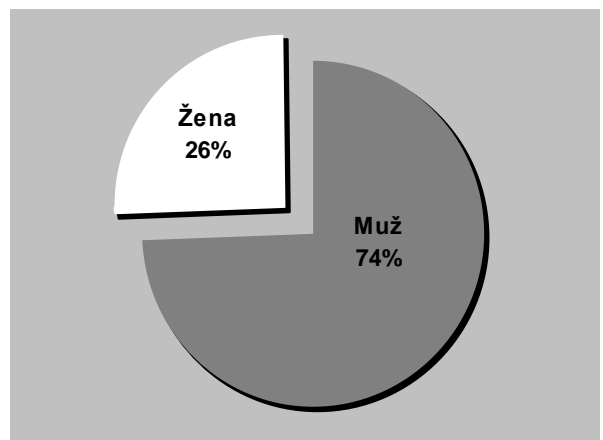

Obrázek 1. Pohlaví respondenti̊

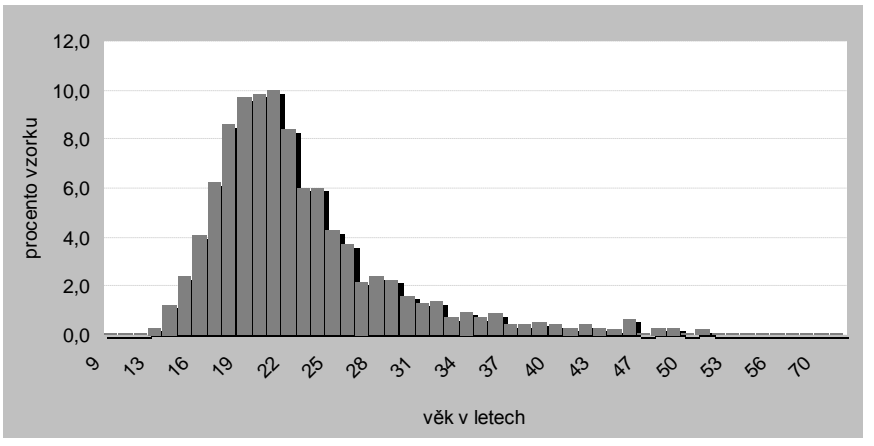

Obrázek 2. Věk respondentů

Za překvapivou zkušenost $\mathrm{z}$ realizace sběru dat touto cestou můžeme považovat skutečnost, že se jen několik respondentů pokusilo data znehodnotit vulgárními či jinak nerelevantními odpověd'mi, tyto byly nadále samozřejmě vyřazeny ze zpracování.

Davson: Ten dotazník je takový moloch s otázkami, které by mě jaktěživ nenapadly, že na něj kašlu :)

Závěrem tak mohu říci, že práce na tomto projektu byla příležitostí k setkání se zajímavými lidmi, díky nimž se průběh vlastního výzkumu stal př́ijemnou zkušeností.

\section{Literatura}

Buckingham, D. (1987). Public secrets: East enders and its audience. London: BFI.

Fisherkeller, J. E. (2000). The writers are getting kind of desperate: Young adolescents, television, and literacy. Journal of Adolescent \& Adult Literacy, 43(7), 596-606.

Harrington, C. L., \& Bielby, D. D. (2007). Global fandom/Global fan studies. In J. Gray, C. Sandvoss, \& C. L. Harrington (Eds.), Fandom. Identities and comunities in a mediated world. New York University Press.

Hendl, J. (2005). Kvalitativní výzkum: základni metody a aplikace. Praha: Portál.

Hills, M. (2002). Fan cultures. New York: Routledge.

Jenkins, H., McPherson, T., \& Shattuc, J. (2002). Hop on pop: The politics and pleasures of popular culture. London: Duke University Press.

Jones, G. (2003). Killing monsters why children need fantasy, super heroes, and make-believe violence. New York: Basic Books.

Krátká, J. (2010). Zkušenostní učení prostřednictvím identifikace s fikčními postavami filmů a seriálů. Brno: MU.

Money, D. (1989). Changing paradigms in audience studies In E. Sester, H. Borschers, H. Kreutzner, \& E. M. Warth (Eds.), Remote control. Television audiences and cultural power (16-43). New York: Routledge.

Reeves, J. L., Roggers, M. C., \& Epstein, M. (1996). Rewriting popularity: The cult files. In D. Lavery, A. Hague, \& M. Cartwright (Eds.), Deny All Knowledge: Reading X-Files. New York: Syracuse University Press.

\section{Kontakt}

Mgr. Jana Krátká, Ph.D.

Masarykova univerzita

Pedagogická fakulta, Katedra pedagogiky

Poříčí 31, 60300 Brno

e-mail: kratka@ped.muni.cz 


\section{Bibliografické údaje}

Krátká, J. (2011). Zkušenosti s užitím online dotazníku na www.csfd.cz jako součásti smíšeného výzkumu. In T. Janík, P. Knecht, \& S. Šebestová (Eds.), Smišený design v pedagogickém výzkumu: Sbornik př́spěvků z 19. výročni konference České asociace pedagogického výzkumu (s. 372-377). Brno: Masarykova univerzita.

Dostupné z: http://www.ped.muni.cz/capv2011/sbornikprispevku/kratka.pdf doi: 10.5817/PdF.P210-CAPV-2012-31 